slight: there were anorexia, restlessness, and general feeling of malaise, but no rise of temperature. General tonic treatment was prescribed, together with full doses of arsenic. The blebs were pricked and dressed with boracic acid and vaseline. Improvement soon took place, but blebs occasionally appeared, and the disesse did not entirely disappear until five or six weeks after the confinement. Following the patient's last three previous confinements, she has had exactly similar attacks; they have usually commenced about the fourth day after delivery, and have lasted for several weeks. The first attack lasted ten weeks; the second also about ten weeks; the third lasted fifteen weeks, and was the most severe of all ; the fourth and last was the mildest, and accompanied with less general disturbance than the others.

Leeds.

\section{AN UNUSUAL CASE OF MUCOUS CYST} BY F。W Grbion, L.R.C.P.E., L.S.A., \&c.

ON Sept. 9th I attended Mrs. G- in confinement of a fine bealthy female child. The following morning the nurse informed me that the infant had not passed urine, and drew my attention to a "tumour" filling up the vaginal cavity, which she attributed as the cause, especially as she said it came down very much when the child cried. On examining the child, I found a large cystic tumour, about the size of a pigeon's egg, which appeared full of pus; and on manipulating it and pressing it to one side the bladder relieved itself. I was puzzled, first, as to its situation, coming from a space between the clitoris and the meatus urinarius; and, secondly, as to its size and consistence, as it could not have arisen in fourteen hours, the time after delivery. However, with a bistoury I slit it up, and the contents were discharged (pure pus), the tumour disappeared, and four days afterwards the walls of the cyst came away. The child has had no other symptoms.

Tyne Dock, South Shields.

\section{A a ditirux}

\section{HOSPITAL PRACTICE, BRITISH AND FOREIGN.}

Tulla autem est alia pro certo noscendi via, nisi quamplurimas et morcorum et dissectionum historias, tum aliorum tum proprias collectas habere, et inter se comparare-Morgagni De Sed. et Caus. Morb. Sib. ir. Procemium.

\section{LONDON HOSPITAL}

A CASE OF GASTROSTOMY FOR GESOPHAGEAL OBSTRUCTION WITH SUCCESSFUL RESULT

(Under the care of Mr. M'CARThy.)

THE following account of a case of successful gastrostomy - successful not only so far as the operation itself was concerned, but also in the relief afforded by it - is interesting; and we hope to be able to publish further details when the case has terminated. Already five months have elapsed, during which the patient has enjoyed comparative comfort, being saved from the dread of impending starvation, and able to make such good use of the opening as to gain flesh and strength. The operation was one specially indicated by the condition of the stricture, which was impassable to even the smallest bougies.

A wharf labourer, aged forty-seven, was admitted on the medical side of the Isondon Hospital, under the care of Dr, Sansom, on April 6th, 1887, for inability to swallow. He said that he had had trouble in swallowing for about ten wreks, but that for the last few days solid food seemed to lodge a little way down his throat, and was then vomited; and that of liquids only a small quantity passed into his stomach, and the greater part was thrown up soon after it had been swallowed. Notwithstanding his assertion that he had lost flesh considerably, he was by no means emaciated, and weighed $137 \mathrm{lb}$. Examination of the throat, internally and externally, disclosed nothing. His heart was normal, and there was no evidence of thoracic aneurysm. Hepatic dulness extended for two inches below the ribs, and there was increased resistance to pressure in the right half of the epigastrium. All attempts to introduce bougies failed. Wven the smallest-sized instrument was arrested about two inches from the commencement of the oesophagus. Nothing could be ascertained from his family and personal history to elucidate his condition. He stated that he had never had syphilis, and there was no indication of that disease. He was occasionally subject to epileptic fits. For three weeks he was fed with nutrient enemata, as any food taken by the mouth was vomited, and many attempts were made ineffectually to pass bougies.

As the man had then lost six pounds in weight, and was becoming very weak, Mr. M'Carthy was requested to accept the case for operation. Accordingly on April 27th the operation was performed. The patient having been anæsthetised, an incision two inches long was made parallel and about three-quarters of an inch internally to the left costal cartilages, the middle of the incision corresponding to the convexity of the ninth cartilage. The skin and fascia having been divided, the skin was drawn inwards so as to expose the sheath of the left rectus abdominis muscle. This was then divided vertically for two inches, and, the muscular fibres having been separated with the handle of the scalpel, the posterior layer of the sheath and the peritoneum were opened vertically for about one inch and a half. Through this opening Mr. M'Carthy introduced one finger and explored the right half of the epigastrium. A hard nodular tumour, about the size of a pullet's egg, could be felt in the upper surface of the liver, but it was quite out of sight. The stomach was then attached to the anterior wall of the abdomen in the usual manner by two rows of sutures round the opening: one of carbolised silk, about three-quarters of an inch from the margin of the opening; and the other of silkworm gut, at the margin itself. The part was then dusted with iodoform and covered with a wood-wool pad.

For four days the patient was fed solely with nutrient enemata. On the fifth day Mr. M'Carthy made a small incision in the stomach wall, and through this, when it had been dilated with a pair of dressing forceps, a soft rubber tube was introduced, and about two teaspoonfuls of eggand-brandy mixture were injected. The patient at once complained of severe pain in the left shoulder and supraclavicular region, which gradually abated after two or three hours. When the house-surgeon, Mr. Walker, repeated the injection at night, similar pain was felt, but after some days the patient ceased to complain of it. During the ensuing forty-eight hours the patient had five epileptic fits, and then became for some days furiously delirious. It was subsequently ascertained that he had been at one time in confinement for insanity. When the delirium subsided, the patient became very apathetic and his conjunctivæ were deeply jaundiced. The stomach was contracted and irritable, and the patient had a troublesome cough, so that for some time very little of what was injected was retained in the stomach, and nutrient enemata were still requisite. Gradually the stomach became more tolerant of food, and the patient improved so much that by the end of May he was able to leave his bed. He was then weighed, and had lost from the time of the operation $22 \mathrm{lb}$, weighing only $108 \mathrm{lb}$. The obstruction in the oesophagus had also diminished, for he was now able to swallow milk, arrowroot, and custard pudding easily. This improvement in swallowing was very temporary, and at present (Oct. 19th) he can only swallow a small quantity of fluid, and this is sometimes immediately vomited. From the end of May his progress has been uninterruptedly good, and his gain in weight considerable, his present weight being $156 \mathrm{lb}$. His general condition is very good, and his only trouble is some excoriation of the skin round the gastric opening, from leakage of fluid from the stomach.

\section{WORCESTER GENERAL INFIRMARY.}

CASE OF PERFORATION OF AN ULCER OF BMALI INTESTINE DUE TO A FALL, ASSOCIATED WITH FRACTURE OF FOUR RIBS BY DIRECT VIOLINCE.

(Under the care of Mr. HYde.)

THe notes of the case were taken by Mr. T. P. Gostling.

Joseph S—, aged sixty-six, was admitted on Sept. 20th, 1887, at 7.30 A.M. He stated that between 11 and 12 P.M. on Sept. 19th he was walking home from Worcester, a distance of three miles, in the road, and stepped on one side to avoid a carriage. As soon as this had passed he stepped into the road again, and turned half round to look after it, when he 